\title{
Enzymatic Hydrolysis of an Organic Sulfur Compound
}

\author{
Terrence G. Gardner ${ }^{1 *}$, Zachary N. Senwo ${ }^{2}$ \\ ${ }^{1}$ Department of Crop and Soil Sciences, North Carolina State University, Raleigh, NC, USA \\ ${ }^{2}$ Department of Biological \& Environmental Sciences, Alabama A\&M University, Normal, AL, USA \\ Email: *Terrence_Gardner@ncsu.edu
}

How to cite this paper: Gardner, T.G. and Senwo, Z.N. (2019) Enzymatic Hydrolysis of an Organic Sulfur Compound. Advances in Enzyme Research, 7, 1-13. https://doi.org/10.4236/aer.2019.71001

Received: February 13, 2019

Accepted: March 26, 2019

Published: March 29, 2019

Copyright (C) 2019 by author(s) and Scientific Research Publishing Inc. This work is licensed under the Creative Commons Attribution International License (CC BY 4.0).

http://creativecommons.org/licenses/by/4.0/

\begin{abstract}
Sulfatases which cleave sulfate esters in biological systems are key enzymes that deserve special attention due to their significant roles in organic sulfur (OS) mineralization and inorganic sulfur $\left(\mathrm{SO}_{4}^{2-}\right)$ release. In this study, in-vitro experiments were conducted to evaluate $\mathrm{S}$ bonded substrate hydrolysis by a commercially available arylsulfatase (EC 3.1.6.1) from Aerobacter aerogenes. The enzyme-substrate interactions were assessed to determine: 1) rate of hydrolysis, 2) catalytic efficiency, 3) thermal stability, and 4) optimal $\mathrm{pH}$ of this enzyme. Arylsulfatase exhibited substrate hydrolysis with a high affinity for $p$-nitrophenyl sulfate (potassium 4-nitrophenyl sulfate ( $p$ NPS)). The optimum activity for the enzyme was observed to occur at a $\mathrm{pH}$ of 7.1. The optimal temperature was $37^{\circ} \mathrm{C}$ but ranged from $35^{\circ} \mathrm{C}-45^{\circ} \mathrm{C}$. The apparent $K_{\mathrm{m}}$ and $K_{\text {cat }}$ of the enzyme for $p$ NPS hydrolysis at the optimal pH, and temperature were determined to be $1.03 \mathrm{mM}$ and $75.73 \mu \mathrm{M} / \mathrm{min}$, respectively. This work defines the catalytic and kinetic properties of arylsulfatase (EC 3.1.6.1) and confirms the optimal conditions for sulfatase activity testing. The resulting information is useful in elucidating the contributions that individual enzymes have for specific reactions rather than relying on traditional total enzyme activity measurements.
\end{abstract}

\section{Keywords}

Enzymes, Sulfatases, Organic Sulfur Mineralization

\section{Introduction}

Sulfatases are a heterogeneous family of enzymes that constitute a biologically and industrially important group of proteins and play critical roles in the hydrolysis of sulfate groups from sulfated biomolecules [1]. The International Union 
of Biochemistry and Molecular Biology (IUBMB) classified the family into 17 classes from EC 3.1.6.1 - EC 3.1.6.18, as deduced from the nucleotide sequence similarities [2], substrate specificity and sensitivity to inhibitors [3]. Although sinigrin sulfohydrolase; myrosulfatase (EC 3.1.6.5) was removed from the group in 1964, the major classes recognized include arylsulfatases (EC 3.1.6.1), steroid sulfatases (EC 3.1.6.2), glucosulfatases (EC 3.1.6.3), chondrosulfatases (EC 3.1.6.4), and alkylsulfatases (EC 3.1.6.19) [4] [5].

Sulfur is documented as being a critical component for plant and animal growth and development, and in several reactions that occur in living cells [6]. However, reductions in $\mathrm{S}$ emissions from industrial sources, decreased use of $\mathrm{S}$ containing fungicides and pesticides, increased use of low $\mathrm{S}$ containing fertilizers, and high yielding crops over the past twenty years have resulted in low $\mathrm{S}$ availability [7] [8]. The deficiencies in plant available $S$ in soils have long been recognized as a cause of delayed maturity, stunting of plants, and interveinal chlorosis in crop productions worldwide [9] [10].

Inorganic $S$ is generally much less abundant than organically bound $\mathrm{S}$ in most agricultural soils [11]. As a result, organic $S$ compounds are typically unavailable to plants. Ester sulfates constitute the most important organic $S$ reserve in aerobic soils accounting for up to about $70 \%$ of the total S in such soils [12]. Organic $\mathrm{S}$ compounds must, therefore, be converted by biochemical hydrolysis of sulfateesters or by microbiological mineralization of $\mathrm{C}$-bonded $\mathrm{S}$ to release inorganic $\mathrm{SO}_{4}^{2-}$ before plant uptake [13]. The hydrolysis of the aromatic ester-sulfate molecule is catalyzed by periplasmically located sulfatases that cleave sulfate from the organic S molecules moiety.

Enzymes of the sulfatase group are major components in the release of $\mathrm{SO}_{4}^{2-}$ from organic sulfur compounds. Sulfatases are found to be intracellular or bound to cell components and abiotic or as extracellular secretions from intact cells or released from dead or lysed cells that originate from the cell membranes [14]. The enzyme focus in this study, for example, arylsulfatase is a class of sulfatase in which both extracellular and intracellular forms have been detected in a wide range of soils, and its activity has been used as a potential indicator for biochemical mineralization of organic ester-sulfates in soils [15] [16]. It has been shown that arylsulfatase in soils is of both plant and microbial origins, and their alterations in soil rhizospheres can cause shifts in the ecology and functionality of the soil microbial communities. The changes in soil microbial communities, therefore, influence the activities of the enzyme and may significantly impact the biochemical mineralization of plant S [15] [17]. Significant positive correlations between arylsulfatase activity and total SOM have been reported [18]. Deng and Tabatabai [18] stated that the actions of arylsulfatase were highly correlated with soil organic $\mathrm{C}$ content and suggested that organic matter plays a vital role in protecting soil enzymes. In many instances, the mineralization of $S$ from soil organic matter increases the supply of $S$ for plant nutrition [6].

Arylsulfatase (aryl-sulfate sulfohydrolase, EC 3.1.6.1) is a class of glycosulfo- 
hydrolase involved in the desulfation of sulfated polysaccharides. It catalyzes the hydrolysis of aryl sulfate-ester bonds, producing aryl compounds and inorganic sulfate $\left(\mathrm{SO}_{4}^{2-}\right)$. Arylsulfatases are found in a wide range of organisms including mammals, bacteria, fungi, and higher plants, and their primary structures are similar to each other although they originate from different species [19] [20]. There have been several reports of arylsulfatases isolated from such bacteria as Pseudomonas [21] [22], Enterobacter [23], Salmonella typhimurium [24], Klebsiella [25], and Serratia [26].

Arylsulfatase enzymes (ARS) are one of the sulfate starvation-induced (SSI) proteins produced by microorganisms during $S$ starvation. Recent studies suggest that in bacteria, these proteins are potentially critical enzymes in the cellular responses against S limitation [14] [27] [28]. Aryl-sulfohydrolase enzymes are implicated in the desulfation of aromatic sulfate esters. In Pseudomonas aeruginosa, the repressive effects in vivo were traced to two independent effectors, sulfites and either sulfides or cysteines whereas, in Klebsiella pneumoniae, sulfate and cysteine repress arylsulfatase synthesis independently of each other [26]. Arylsulfatases have been classified as type I and II according to their substrate specificity and sensitivity to inhibitors. Type I enzymes are specific for $p$-nitrophenyl sulfate ( $p$ NPS) and $p$-acetylphenyl phosphate substrates and are inhibited by cyanide [29] [30]. Type II enzymes are more catalytic on $p$-nitrocatechol sulfate ( $p$ NCS) (2-hydroxy-5-nitrophenyl sulfate) and are inhibited by phosphate and sulfate [14]. However, to survive under sulfate-limiting conditions, microorganisms will have to synthesize SSI proteins to fulfill their S requirements [14].

Specific for the catalyzed reaction, the proficiency of an enzyme as a catalyst and its similar affinity for an altered substrate in the transition state can be assessed by comparing the $K_{\mathrm{cat}} / K_{\mathrm{m}}$, with the rate constant of the corresponding reaction under similar conditions and in the absence of a catalyst [31]. Some enzymes catalyze slow reactions while others are involved in fast reactions. Those enzymes that catalyze slow reactions are of interest because they offer sensitive targets for inhibition by transition-state analogs [32]. The stereochemical and stereoisomeric structures of the substrate or the types of elements attached to it will also influence hydrolysis rates [33]. Enzymes have specific atomic configurations on their active sites and, any modifications to the substrates that are specific for a particular enzyme will likely denature the enzyme rendering the protein ineffective. Such parameters as time, $\mathrm{pH}$, temperature, and enzyme concentration influence enzymatic activity co-operatively.

Our understanding of the precise roles and functions of sulfatase enzymes in mineralizing organic S especially in soils is constrained to some extent by limitations of the methods used since there is no standard method to determine soil enzyme reactions or hydrolysis. Para-nitrophenyl sulfate ( $p$ NPS) is a widely used substrate for assays of soil arylsulfatase activities; however, it may not accurately reflect the relative hydrolysis of various soil sulfatases. Thus, understanding the 
behavior of enzymes in pure systems with different substrate concentrations and identifying the contributions the individual proteins have for specific reactions rather than relying on total enzyme activities, as has been the case with traditional assay methods, would improve our understanding of enzyme hydrolysis in terrestrial and aquatic environments.

With this study, we focused on a commercially available sulfatase from Aerobacter aerogenes. The enzyme was selected because most early work on the regulation of arylsulfatase synthesis was performed with Aerobacter aerogenes [34]. This organism synthesizes arylsulfatase when grown in medium containing methionine, taurine or choline sulfate as the sulfur source (non-repressed condition). The synthesis is; however, repressed using inorganic sulfate, or any of the sulfur compounds which are thought to be direct intermediates in the conversion of sulfate to cysteine as the sulfur source [34]. The goals are to determine the catalytic and kinetic properties of arylsulfatase (EC 3.1.6.1), using organic $S$ compounds as substrates. This paper reports the features of the enzyme from Aerobacter aerogenes. Information obtained will also aid in the scientific predictions in rate-limiting steps during the decomposition or degradation of organic matter and transformation of soil elements [35].

\section{Materials and Methods}

\subsection{Organic Sulfate Compound and Enzyme}

P-nitrophenyl sulfate (potassium 4-nitrophenyl sulfate) ( $p$ NPS) substrate (Figure 1), and arylsulfatase from Aerobacter aerogenes were used without further purification in this study. Both, the organic sulfate compound and the enzyme, were purchased from Sigma-Aldrich, St. Louis, Missouri, USA.

\subsection{Assay Buffer and Conditions}

The optimal $\mathrm{pH}$ for the arylsulfatase as reported by the manufacturer was 5.0, and the optimal temperature is $37^{\circ} \mathrm{C}$. One unit $(\mathrm{U})$ of the enzyme was reported to liberate $1.0 \mu \mathrm{mol} p$-nitrocatechol sulfate per hour at the proper $\mathrm{pH}$ and temperature. Two concentrations of the $\left(0.05 \mathrm{U} \cdot \mathrm{mL}^{-1}\right.$ and $\left.0.033 \mathrm{U} \cdot \mathrm{mL}^{-1}\right)$ of the arylsulfatase enzyme was used to hydrolyze the $p$-nitrophenyl sulfate substrate ( $p$ NPS). The effects of $\mathrm{pH}$, temperature, and time on the enzyme-substrate

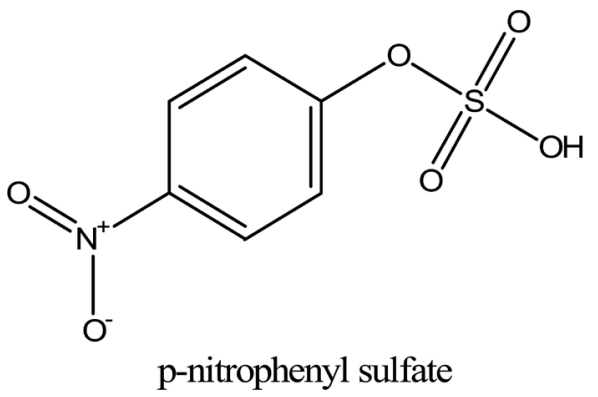

Figure 1. Substrate structure. 
reaction was determined by incubation using a wide range of temperatures ranging from $10^{\circ} \mathrm{C}$ to $80^{\circ} \mathrm{C} ; \mathrm{pH}$ ranging from 2 to 9 , and time ranging from 1 to 10 hours, using $p$ NPS substrate concentration of 5 times the $K_{\mathrm{m}}$ [36].

\subsection{Kinetic Determination}

The substrate concentrations used to establish the kinetic parameters in the assays ranged from 0 to $12 \mathrm{mM}$. The enzyme activity was estimated by measuring the rate of inorganic $\mathrm{SO}_{4}^{2-}$ (product) released and determined using methods described by Tabatabai and Bremner [4] and Dodgson and Spencer [37]. The sulfate compound (substrate) was dissolved in a $0.5 \mathrm{M}$ acetate buffer solution, $\mathrm{pH} 5.8$, with final enzyme concentrations of $0.05 \mathrm{U} \cdot \mathrm{mL}^{-1}$ and $0.033 \mathrm{U} \cdot \mathrm{mL}^{-1}$. All reaction mixtures were carried out at a total volume of $3 \mathrm{~mL}$. At the end of incubation, the reaction was stopped by adding $0.5 \mathrm{~N} \mathrm{NaOH}$, and $0.5 \mathrm{M} \mathrm{CaCl}_{2}$ to the product. The intensity of yellow color produced (due to the liberation of $\mathrm{SO}_{4}^{2-}$ from $p$ NPS substrate) was measured at $400 \mathrm{~nm}$ with a spectrophotometer (Thermo Electron Corp. Model: Genesys 10 UV). Standard curves derived from spectrophotometric readings of known concentrations of $\mathrm{SO}_{4}^{2-}$ were used to calculate the sulfate concentrations in test solutions. The controls were established by incubating the substrate without enzyme to correct for the inorganic $\mathrm{S}$ released due to chemical hydrolysis. The amount of inorganic $\mathrm{SO}_{4}^{2-}$ issued was determined colorimetrically. The resulting data was plotted against substrate concentration. The initial rates of inorganic $S$ released versus substrate concentrations were fitted to the Michaelis-Menten equation:

$$
V=\frac{V_{\max }[\mathrm{S}]}{K_{m}+[\mathrm{S}]}
$$

To study the effects of incubation time, temperature and $\mathrm{pH}$ on enzyme activity, these conditions were varied while using an excess of substrate $(1.0 \mathrm{mM})$. The Michaelis-Menten enzyme model was used to determine the kinetic parameters. The constant $\left(K_{m}\right)$, and maximum rate $\left(V_{\max }\right)$ were calculated by way of non-linear regression analysis using GraphPad Prism version 4.00 statistical software (GraphPad Prism Software, Inc. Ca, USA).

The measurements to determine the temperature coefficients $\left(Q_{10}\right)$ were at intervals of $10^{\circ} \mathrm{C}$ (between $20^{\circ} \mathrm{C}$ and $80^{\circ} \mathrm{C}$ ); while the activation energy $\left(E_{\mathrm{a}}\right.$ ), was assessed using the Arrhenius equation. Except otherwise stated, experiments were conducted in triplicate.

\section{Results and Discussion}

\subsection{Activation Energies and Kinetic Parameters}

The data obtained for arylsulfatase activity from the bacterial source (Aerobacter aerogenes), was fitted to the Michaelis-Menten enzyme kinetics to determine the $K_{\mathrm{m}}$ and $V_{\max }$ values for the substrate used. The $V_{\max }$ is dependent on enzyme concentration and is defined as the velocity obtained when the enzyme is satu- 
rated. The $K_{\mathrm{m}}$ values are considered to be a measure of enzyme affinity for the substrate. The lower $K_{\mathrm{m}}$ value, the higher the enzyme affinity for the substrate [38]. In this study, the $K_{\mathrm{m}}$ value for the purified arylsulfatase from Aerobacter aerogenes resulted in a concentration of $1.03 \mathrm{mM}$. Comparably, the $K_{\mathrm{m}}$ of arylsulfatase purified from Aerobacter aerogenes in a separate study was valued at $0.187 \mathrm{mM}$ [39]. Pseudomonas aeruginosa activity was measured as sulfate released from 4-nitrocatechol sulfate and was assessed at $0.10^{5} \mathrm{mM}$ [40]. Okamura et al., [34] reported a much higher $K_{\mathrm{m}}$ value of arylsulfatase purified from the bacteria, Klebsiella aerogenes $(9.0 \mathrm{mM})$. Although the enzymes were able to hydrolyze various aromatic sulfate esters, lower values were obtained in our study, indicating high enzyme affinity for $p$ NPS. The variations in $K_{\mathrm{m}}$ appear to reflect the differences in substrate concentrations and the types and sources of the enzymes.

The maximum velocity ( $V_{\max }$ ) of the enzyme, reveals the number of substrate molecules converted into products by an enzyme molecule in a unit time when the catalyst is fully saturated with substrate [41]. Our results indicate the $V_{\max }$, of the enzyme from Aerobacter aerogenes, was $75.7 \mathrm{uM} / \mathrm{min}$.

The enzyme turnover number $K_{c a t}$ represents the number of substrate molecules each enzyme site converts to product per unit time. The enzymatic activity in this study was valued at $1.5 \times 10^{3} \mathrm{~s}^{-1}$ which; is equal to the kinetic constant. High $K_{c a t}$ values indicate greater enzyme specificity for catalyzing the substrate reaction. Tazisong et al. [42] and Berg et al. [41] reported that the $K_{c a t}$ of most enzymes associated with their physiological substrates is typically found in the range of 1 to $10^{4} \mathrm{~s}^{-1}$. The specificity constant, $K_{c a t} / K_{m}$, incorporates the rate constants for all the reaction steps used to measure the catalytic efficiency of the enzyme-substrate reaction. The $K_{c a t} / K_{m}$ in this assessment was valued at $8.7 \times 10^{5}$ $\mathrm{M}^{-1} \cdot \mathrm{s}^{-1}$. Typically high $K_{c a t} / K_{m}$ values indicate higher enzyme affinity for the substrate.

\subsection{Effects of Substrate Concentrations, Time, Temperature and pH on Activity}

Arylsulfatase seemed to show absolute specificity to the substrate ( $p$ NPS) used. The initial rate of substrate hydrolysis was measured at various substrate concentrations (Figure 2). Reaction velocities increased as substrate concentration was increased. At $4 \mathrm{mM}$ the reaction is likely to follow zero-order kinetics. The effect of incubation time on arylsulfatase activity is shown in Figure 3. The activity with time was linear for up to two hours, which was used to assess kinetic parameters. The curve then losses curve linearity which indicates enzyme saturation or product inhibition. The Aerobacter aerogenes sulfatase was stable between $35^{\circ} \mathrm{C}$ to $45^{\circ} \mathrm{C}$. The optimum temperature for the arylsulfatase was at $37^{\circ} \mathrm{C}$ is shown in Figure 4. The enzyme was active in temperatures approaching $39^{\circ} \mathrm{C}$ but was inactivated at temperatures $>40^{\circ} \mathrm{C}$. The kinetic energy of molecules will increase with increasing temperatures, leading to more frequent collisions and 


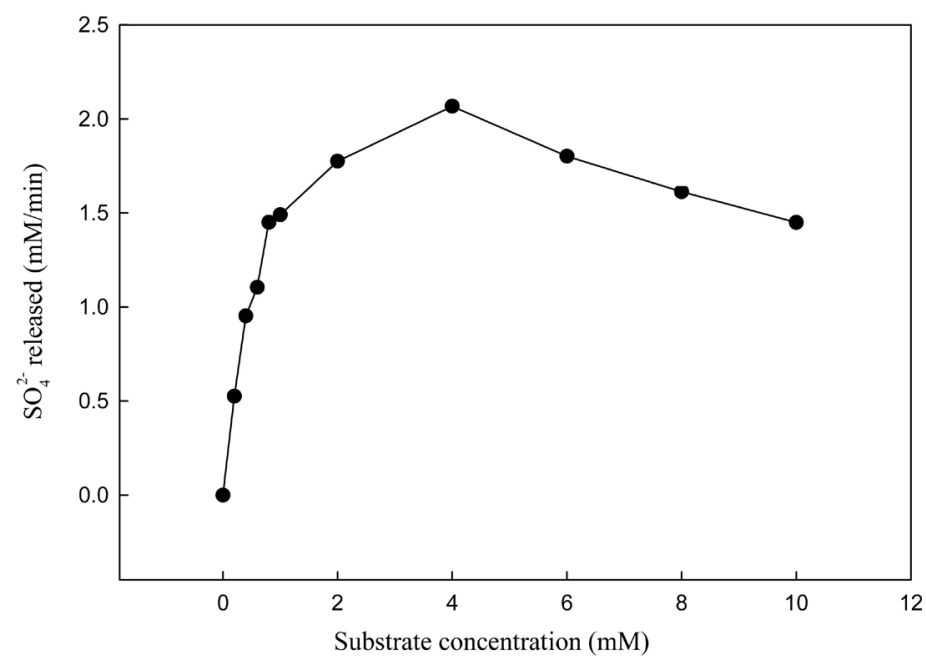

Figure 2. Effect of substrate concentration on arylsulfatase activity.

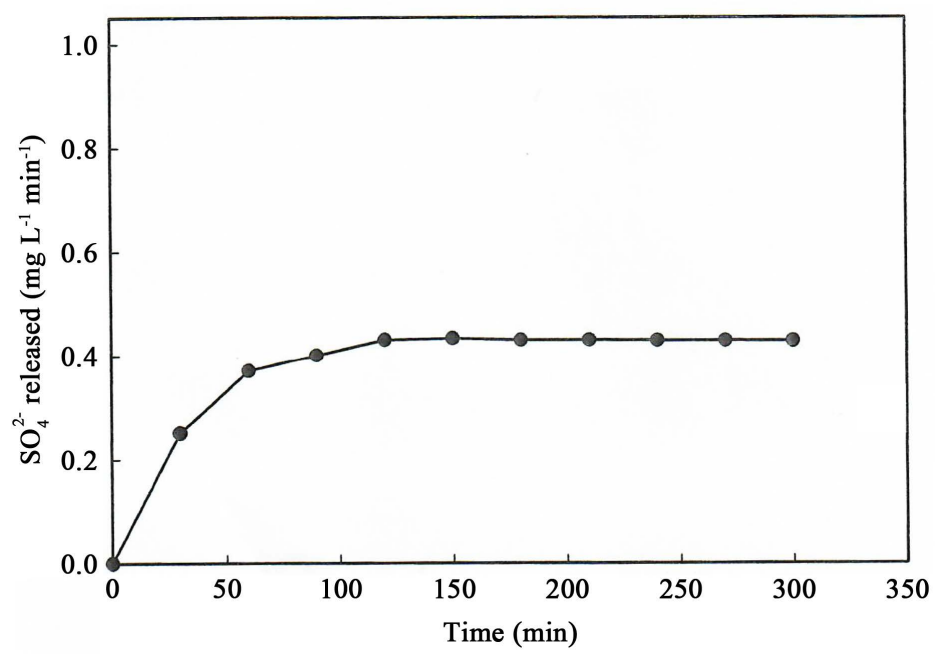

Figure 3. Effect of incubation time on arylsulfatase activity.

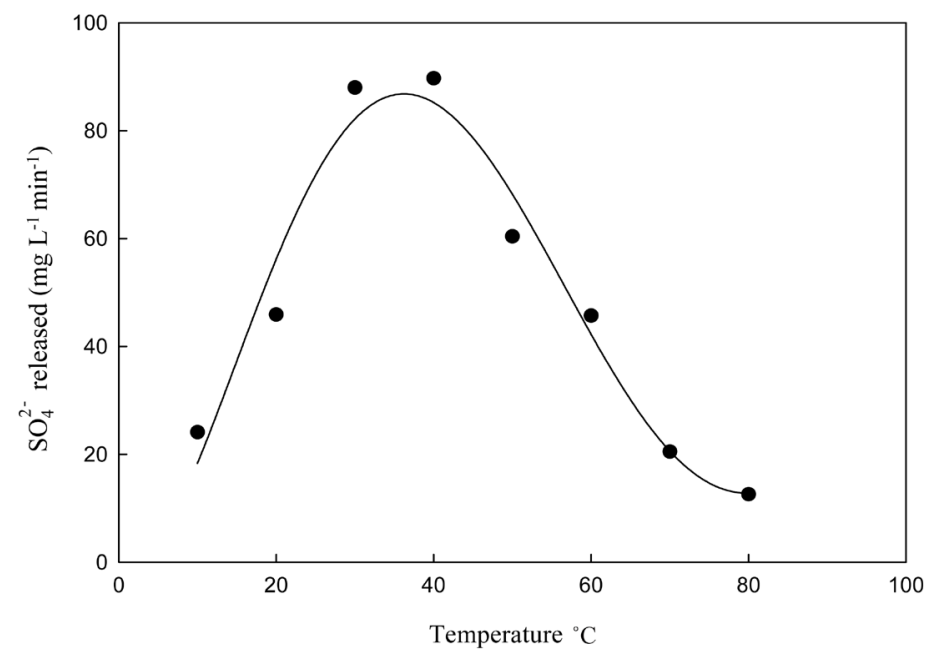

Figure 4. Effect of temperature on arylsulfatase activity. 
increase in reaction rates. Increasing the kinetic energy after attaining the optimal temperature causes the hydrogen bonds and hydrophobic interactions to split. The active sites begin to lose shape, and the enzyme denatures. The observation of various optimal temperatures with multiple substrates and the same enzyme may be due to conformational changes induced on the catalyst after the substrate binds. The conformational change induced on the protein may either delay or hasten the collapse of hydrogen and hydrophobic interactions [43].

Variations in $\mathrm{pH}$ affect the ionic forms of the enzyme active sites, therefore changing the activities and reactions rates. Enzymes are proteins that contain amino acids, have basic, neutral, or acid side groups which are positively or negatively charged contingent on the $\mathrm{pH}$. As a result, the $\mathrm{pH}$ may cause a conformational change in the structure, the maximum reaction rate $\left(K_{m}\right)$, the enzyme stability and the substrate affinity for the enzyme, if the substrate contains ionic groups [44]. The $\mathrm{pH}$ optimum of the purified enzyme was determined over a $\mathrm{pH}$ range of 3.0 to 9.0, using a concentration 5 times the $K_{m}$ [45]. The enzyme was active in the $\mathrm{pH}$ range 6.0 to 7.5 with the maximal hydrolysis of $p \mathrm{NPS}$ at the $\mathrm{pH}$ of 7.1 (Figure 5). At higher $\mathrm{pH}$, the enzyme activity gradually decreased. The $\mathrm{pH}$ of arylsulfatase with $p$ NPS was two units more elevated than that reported by the supplier.

The activation energy $\left(E_{a}\right)$ was calculated based on the Arrhenius equation (Equation (1.3)).

$$
\ln k=\left(-E_{a} / R\right)(1 / T)+\ln A
$$

$E_{a}$ was calculated from the slope of the linear relationship by plotting $\ln k$ versus $1 / T$ (Figure 6 ). The $E_{a}$ values are indicative of the energy barrier that must be overcome to drive a reaction forward. The $E_{a}$ value is nearly equal to the difference in energy between the reactants and the transition state [46]. The calculated sulfatase $E_{a}$ expressed for this study ranged from 18.0 to $36.1 \mathrm{~kJ} \cdot \mathrm{mole}^{-1}$.

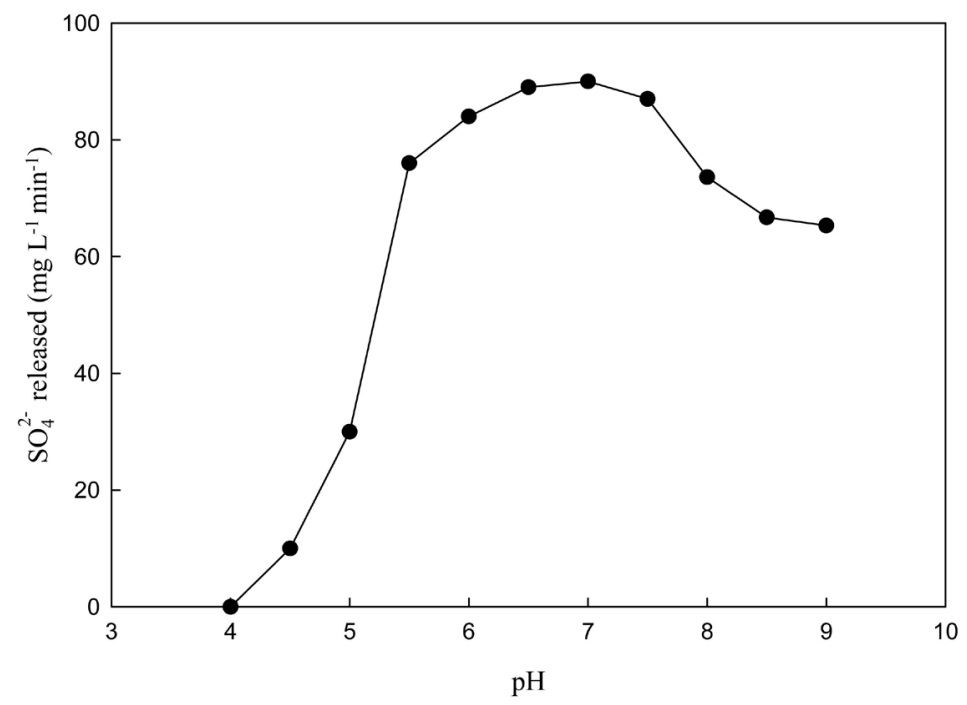

Figure 5. Effect of $\mathrm{pH}$ on arylsulfatase activity. 


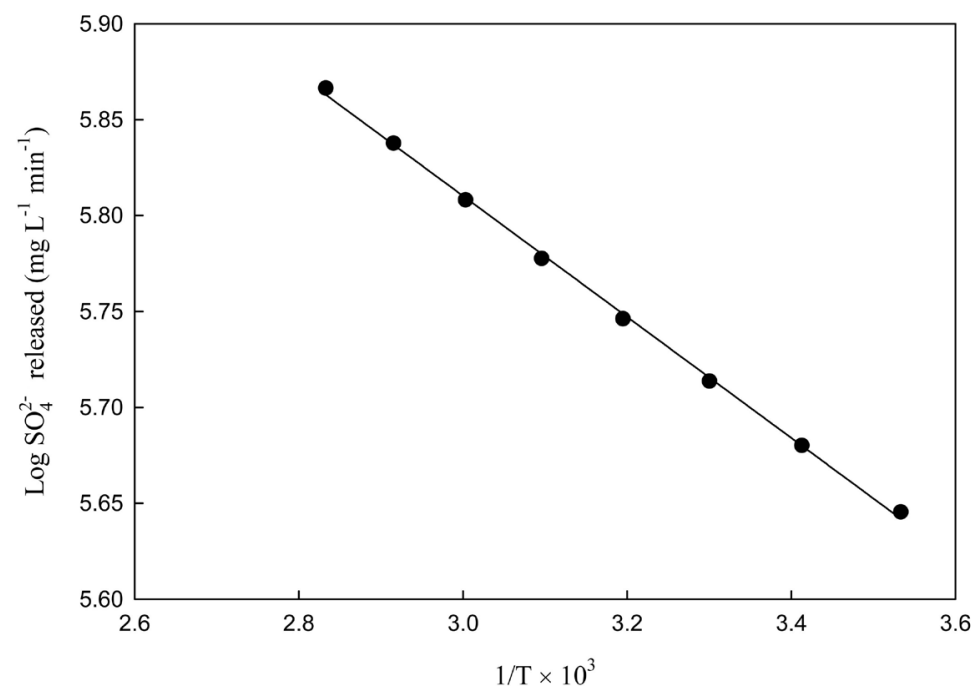

Figure 6. Arrhenius equation plot of arylsulfatase activity.

The temperature coefficient $\left(Q_{10}\right)$, is used to measure the rate of change that occurs in biological or chemical systems as a result of $10^{\circ} \mathrm{C}$ temperature increases. The $Q_{10}$ in this study was obtained by calculating the effect of $10^{\circ} \mathrm{C}$ temperature changes on the activity of the enzyme during incubation. The enzyme activity followed the Equation (1.4) below:

$Q_{10}=$ Activity at given temperature/Activity at given temperature $-10^{\circ} \mathrm{C}(1.4)$

The average $Q_{10}$ for Aerobacter aerogenes enzyme between $20^{\circ} \mathrm{C}$ and $80^{\circ} \mathrm{C}$ ranged from $1.90-0.61$.

\section{Conclusion}

Based on this research and other studies, the rate of hydrolysis, catalytic efficiencies, thermal stabilities, and optimal $\mathrm{pH}$ values of enzymes may depend on the enzyme sources and the stereochemical or stereoisomeric structures of the substrates. The optimum $\mathrm{pH}$ for the sulfatase was observed to be 7.1. The kinetic differences observed, evidenced by other available reports on this topic suggest that enzymes are distinct and have distinct functions. Several microorganisms exhibit multiple arylsulfatase activities, which are generally subject to repression by a variety of $S$ compounds. Little is known of the regulation of the individual enzymes; however, there is evidence that suggests distinct regulatory control of synthesis.

\section{Acknowledgements}

This work is a contribution from the Winfred Thomas Agricultural Research Station, Alabama A \& M University, Normal, AL, and Department of Crop and Soil Sciences, North Carolina State University, Raleigh, NC. Trade or manufacturers' names mentioned in the paper are for information purposes only and do not constitute endorsement, recommendation, or exclusion by either Alabama $\mathrm{A}$ 
\& M University or North Carolina State University. The research was supported by USDA-NIFA, Evans-Allen Grant\# ALAX 011.

\section{Conflicts of Interest}

The authors declare no conflicts of interest regarding the publication of this paper.

\section{References}

[1] Barbeyron, T., Brillet-Guéguen, L., Carré, W., Carrière, C., Caron, C., Czjzek, M., Hoebeke, M. and Michel, G. (2016) Matching the Diversity of Sulfated Biomolecules: Creation of a Classification Database for Sulfatases Reflecting Their Substrate Specificity. PLoS ONE, 11, e0164846.

[2] De Hostos, E.L., Schilling, J. and Grossman, A.R. (1989) Structure and Expression of the Gene Encoding the Periplasmic Arylsulfatase of Chlamydomonas reinhardtii. Molecular and General Genetics MGG, 218, 229-239. https://doi.org/10.1007/BF00331273

[3] Dodgson, K.S., White, G.F. and Fitzgerald, J.W. (2018) Sulfatases of Microbial Origin. CRC Press, Boca Raton.

[4] Tabatabai, M.A. and Bremner, J.M. (1970) Arylsulfatase Activity of Soils. Soil Science Society of America Journal, 34, 225-229. https://doi.org/10.2136/sssaj1970.03615995003400020016x

[5] Tabatabai, M.A. and Bremner, J.M. (1970) Factors Affecting Soil Arylsulfatase Activity. Soil Science Society of America Journal, 34, 427-429. https://doi.org/10.2136/sssaj1970.03615995003400030023x

[6] Riffaldi, R., Saviozzi, A., Cardelli, R., Cipolli, S. and Levi-Minzi, R. (2006) Sulphur Mineralization Kinetics as Influenced by Soil Properties. Biology and Fertility of Soils, 43, 209-214. https://doi.org/10.1007/s00374-006-0095-4

[7] Crozier, C., Hoyt, G. and Hardy, D. (2014) Soil Facts: Sulfur Fertilization of North Carolina Crops. NC State Extension Publications, Raleigh. https://content.ces.ncsu.edu/sulfur-fertilization-of-north-carolina-crops

[8] Raper, T.B., Mcclure, A.T., Yin, F. and Brown, B. Sulfur and Tennessee Row Crops Sulfur and Tennessee Row Crops 2.

https://extension.tennessee.edu/publications/Documents/W435.pdf

[9] Scherer, H.W. (2009) Sulfur in Soils. Journal of Plant Nutrition and Soil Science, 172, 326-335. https://doi.org/10.1002/jpln.200900037

[10] Siwik-Ziomek, A., Lemanowicz, J. and Koper, J. (2016) Arylsulphatase Activity and Sulphate Content in Relation to Crop Rotation and Fertilization of Soil. International Agrophysics, 30, 359-367. https://doi.org/10.1515/intag-2015-0098

[11] Bohn, H.L. and McNeal, B.L. (2001) Soil Chemistry. 3rd Edition, John Wiley \& Sons, Inc., New York.

[12] Freney, J.R. (1986) Forms and Reactions of Organic Sulfur Compounds in Soils. In: Sulfur in Agriculture, American Society of Agronomy, Crop Science Society of America, Soil Science Society of America, Madison, WI, 207-232.

[13] Castellano, R.P. and Dick, S.D. (1991) Cropping and Sulfur Fertilization Influence on Sulfur Transformations in Soil. Soil Science Society of America Journal, 54, 114-121. https://doi.org/10.2136/sssaj1991.03615995005500010020x 
[14] Cregut, M., Piutti, S., Slezack-Deschaumes, S. and Benizri, E. (2013) Compartmentalization and Regulation of Arylsulfatase Activities in Streptomyces sp., Microbacterium $s p$. and Rhodococcus sp. Soil Isolates in Response to Inorganic Sulfate Limitation. Microbiological Research, 168, 12-21. https://doi.org/10.1016/j.micres.2012.08.001

[15] Farrell, R.E., Gupta, V.V.S.R. and Germida, J.J. (1994) Effects of Cultivation on the Activity and Kinetics of Arylsulfatase in Saskatchewan Soils. Soil Biology and Biochemistry, 26, 1033-1040. https://doi.org/10.1016/0038-0717(94)90118-X

[16] Gardner, T., Acosta-Martinez, V., Senwo, Z. and Dowd, S.E. (2011) Soil Rhizosphere Microbial Communities and Enzyme Activities under Organic Farming in Alabama. Diversity, 3, 308-328. https://doi.org/10.3390/d3030308

[17] Gupta, V.V.S.R. and Germida, J.J. (1988) Distribution of Microbial Biomass and Its Activity in Different Soil Aggregate Size Classes as Affected by Cultivation. Soil Biology and Biochemistry, 20, 777-786. https://doi.org/10.1016/0038-0717(88)90082-X

[18] Deng, S.P. and Tabatabai, M.A. (1996) Effect of Tillage and Residue Management on Enzyme Activities in Soils. Biology and Fertility of Soils, 22, 208-213. https://doi.org/10.1007/BF00382514

[19] Kertesz, M.A. (2000) Riding the Sulfur Cycle-Metabolism of Sulfonates and Sulfate Esters in Gram-Negative Bacteria. FEMS Microbiology Reviews, 24, 135-175.

[20] Klose, S., Bilen, S., Tabatabai, M.A. and Dick, W.A. (2011) Sulfur Cycle Enzymes. In: Dick, R.P., Ed., Methods of Soil Enzymology, Soil Science Society of America, Wisconsin.

[21] Beil, S., Kehrli, H., James, P., Staudenmann, W., Cook, A.M., Leisinger, T. and Kertesz, M.A. (1995) Purification and Characterization of the Arylsulfatase Synthesized by Pseudomonas aeruginosa PAO during Growth in Sulfate-Free Medium and Cloning of the Arylsulfatase Gene (atsA). European Journal of Biochemistry, 229, 385-394. https://doi.org/10.1111/j.1432-1033.1995.0385k.x

[22] Boltes, I., Czapinska, H., Kahnert, A., Von Bülow, R., Dierks, T., Schmidt, B., Von Figura, K., Kertesz, M.A. and Usón, I. (2001) 1.3 Å Structure of Arylsulfatase from Pseudomonas aeruginosa Establishes the Catalytic Mechanism of Sulfate Ester Cleavage in the Sulfatase Family. Structure, 9, 483-491. https://doi.org/10.1016/S0969-2126(01)00609-8

[23] Fowler, L.R. and Rammler, D.H. (1964) Sulfur Metabolism of Aerobactor aerogenes II. The Purification and Some Properties of a Sulfatase. Biochemistry, 3, 230-237. https://doi.org/10.1021/bi00890a015

[24] Henderson, M. and Milazzo, F.H. (1979) Arylsulfatase in Salmonella Typhimurium: Detection and Influence of Carbon Source and Tyramiine on Its Sysnthesis. Journal of Bacteriology, 139, 80-87.

[25] Miech, C., Dierks, T., Selmer, T., Von Figura, K. and Schmidt, B. (1998) Arylsulfatase from Klebsiella Pneumoniae Carries a Formylglycine Generated from a Serine. Journal of Biological Chemistry, 273, 4835-4837.

[26] Murooka, Y., Yim, M.H. and Harada, T. (1980) Formation and Purification of Serratia Marcescens Arylsulfatase. Applied and Environmental Microbiology, 39, 812-817. http://www.ncbi.nlm.nih.gov/pubmed/16345546

[27] Hummerjohann, J., Küttel, E., Quadroni, M., Ragaller, J., Leisinger, T. and Kertesz, M.A. (1998) Regulation of the Sulfate Starvation Response in Pseudomonas aeruginosa: Role of Cysteine Biosynthetic Intermediates. Microbiology, 144, 1375-1386. 
https://doi.org/10.1099/00221287-144-5-1375

[28] Quadroni, M., James, P., Dainese-Hatt, P. and Kertesz, M.A. (1999) Proteome Mapping, Mass Spectrometric Sequencing and Reverse Transcription-PCR for Characterization of the Sulfate Starvation-Induced Response in Pseudomonas aeruginosa PAO1. European Journal of Biochemistry, 266, 986-996. https://doi.org/10.1046/j.1432-1327.1999.00941.x

[29] Fromageot, C. (1950) Sulfatase. In: Summer, J.B. and Myrbäck, K., Eds., The Enzymes, Vol. 1, Academic Press, New York, 517-526.

[30] Roy, A.B. (1971) The Hydrolysis of Sulfate Esters. The Enzymes, 5, 1-19. https://doi.org/10.1016/S1874-6047(08)60084-0

[31] Lad, C., Williams, N.H. and Wolfenden, R. (2003) The Rate of Hydrolysis of Phosphomonoester Dianions and the Exceptional Catalytic Proficiencies of Protein and Inositol Phosphatases. Proceedings of the National Academy of Sciences of the United States of America, 100, 5607-5610. https://doi.org/10.1073/pnas.0631607100

[32] Gao, J., Ma, S., Major, D.T., Nam, K., Pu, J. and Truhlar, D.G. (2006) Mechanisms and Free Energies of Enzymatic Reactions. Chemical Reviews, 106, 3188-3209.

[33] Chae, M.Y., Postula, J.F. and Raushel, F.M. (1994) Stereospcific Enzymatic Hydrolysis of Phosphorus-Sulfur Bonds in Chiral Organophosphate Triesters. Bioorganic and Medicinal Chemistry Letters, 4, 1473-1478. https://doi.org/10.1016/S0960-894X(01)80516-3

[34] Okamura, H., Yamada, T., Murooka, Y. and Harada, T. (1976) Purification and Properties of Arylsulfatase of Klebsiella Aerogenes Identity of the Enzymes Formed by Non-Repressed and De-Repressed Synthesis. Agricultural and Biological Chemistry, 40, 2071-2076. https://doi.org/10.1271/bbb1961.40.2071

[35] Acosta-Martínez, V., Zobeck, T.M. and Allen, V. (2004) Soil Microbial, Chemical and Physical Properties in Continuous Cotton and Integrated Crop-Livestock Systems. Soil Science Society of America Journal, 68, 1875-1884. https://doi.org/10.2136/sssaj2004.1875

[36] Malcolm, R. (1982) Assessment of Phophatase Activity in Soils. Soil Biology and Biochemistry, 15, 403-408. https://doi.org/10.1016/0038-0717(83)90003-2

[37] Dodgson, K.S. and Spencer, B. (1953) Studies on Sulphatases. 5. The Determination of Inorganic Sulphate in the Study of Sulphatases. The Biochemical Journal, 55, 436-440. https://doi.org/10.1042/bj0550436

[38] Berg, J., Tamoczko, J. and Stryer, L. (2003) Biochemistry. W.H. Freeman and Company, New York.

https://books.google.com/books?hl=en\&lr=\&id=827dBgAAQBAJ\&oi=fnd\&pg=PR6 \&dq=Berg,+J.M.,+Tymoczko,+J.L.+and+Stryer,+L.+(2003+biochemistry.+W.H.+Fr ee-man+and+company,+New+Yok\&ots=jBZzj6ciGY\&sig=L54YnhgmyI8Ro1nuNe q8ch0zIeY\#v=onepage\&q=Berg\%2C\%20J.M.\%2C\&f=false

[39] Yoon, H.Y., Kim, H.J., Jang, S. and Hong, J.I. (2017) Detection of Bacterial Sulfatase Activity through Liquid-And Solid-Phase Colony-Based Assays. AMB Express, 7, Article ID: 826. https://doi.org/10.1186/s13568-017-0449-3

[40] Kertesz, M.A., Kölbener, P., Stockinger, H., Beil, S. and Cook, A.M. (1994) Desulfonation of Linear Alkylbenzenesulfonate Surfactants and Related Compounds by Bacteria. Applied and Environmental Microbiology, 60, 2296-2303. http://www.ncbi.nlm.nih.gov/pubmed/16349317

[41] Berg, J.M., Tymoczko, J.L. and Stryer, L. (2007) The Michaelis-Menten Equation Describes the Kinetic Properties of Many Enzymes. In: Berg, J.M., Tymoczko, J.L. 
and Stryer, L., Eds., Biochemistry, 5th Edition, W. H. Freeman and Company, New York, 216-228.

https://www.ncbi.nlm.nih.gov/books/NBK22430/

[42] Tazisong, I.A., Senwo, Z.N. and He, Z. (2015) Phosphatase Hydrolysis of Organic Phosphorus Compounds. Advances in Enzyme Research, 3, 39-51.

https://doi.org/10.4236/aer.2015.32005

[43] Camilloni, C., Bonetti, D., Morrone, A., Giri, R., Dobson, C.M., Brunori, M., Gianni, S. and Vendruscolo, M. (2016) Towards a Structural Biology of the Hydrophobic Effect in Protein Folding. Scientific Reports, 6, Article No. 28285. https://doi.org/10.1038/srep28285

[44] Ntoko, F.A. and Senwo, Z.N. (2012) Nitrate Reduction by Commercially Available Nitrate Reductases: Bio-Catalytic Potentials and Enzymatic Activities in the Presence of Metals Ions. Journal of Environmental Science and Health, Part A, 47, 2028-2034. https://doi.org/10.1080/10934529.2012.695572

[45] Kim, D.E., Kim, K.H., Bae, Y.J., Lee, J.H., Jang, Y.H. and Nam, S.W. (2005) Purification and Characterization of the Recombinant Arylsulfatase Cloned from Pseudoalteromonas carrageenovora. Protein Expression and Purification, 39, 107-115. https://doi.org/10.1016/j.pep.2004.09.007

[46] Parham, J.A. and Deng, S.P. (2000) Detection, Quantification and Characterization of $\beta$-Glucosaminidase Activity in Soil. Soil Biology and Biochemistry, 32, 1183-1190. https://doi.org/10.1016/S0038-0717(00)00034-1 